\title{
ASSESSMENT OF PHLEBITIS, INFILTRATION AND EXTRAVASATION EVENTS IN NEONATES SUBMITTED TO INTRAVENOUS THERAPY a
}

\author{
Avaliação da ocorrência de flebite, infiltração e extravasamento em neonatos \\ submetidos à terapia intravenosa \\ Avaliacion de la ocurrencia de flebitis, infiltración y extravasamiento en neonatos
submetidos a terapia intravenosa
}

Ana Caroline Rodrigues Gomes ${ }^{1}$
Jane Cristina de Oliveira Faria ${ }^{4}$

Charlione Aparecida Gomes da Silva²

Ariane Ferreira Machado Avelar ${ }^{5}$
Carmen Justina Gamarra ${ }^{3}$

Elisa da Conceição Rodrigues ${ }^{6}$

\section{RESUMO}

This study aimed to describe phlebitis, infiltration and extravasation events in newborn infants hospitalized at the neonatal intensive care unit of a public maternity in Rio de Janeiro, Brazil. A quantitative and descriptive study was carried out, involving 36 newborns under intravenous therapy and indicated for the removal of the peripheral intravenous device. Fifty puncture sites were assessed immediately after the peripheral catheter removal, resulting in an average 1.40 punctures per infant. Complications were responsible for $48 \%$ of catheter removals before discharge from treatment, predominantly infiltration $(79.2 \%)$, followed by phlebitis (16.7\%) and extravasation (4.2\%). To avoid aggravations and enhance the security of newborns submitted to intravenous therapy, the nursing team should periodically assess the peripheral venous access and gain knowledge on interventions needed when signs of complications are detected.

Key words. Nursing. Infant, Newborn. Catheterization, Peripheral. Infusions, Intravenous.

\begin{abstract}
0 objetivo deste estudo foi descrever a ocorrência de flebite, infiltração e extravasamento em recém-nascidos internados na unidade de terapia intensiva neonatal de uma maternidade pública do Rio de Janeiro. Trata-se de um estudo quantitativo descritivo com 36 recém-nascidos em uso de terapia intravenosa e com indicação de remoção do dispositivo intravenoso periférico. Foram avaliados 50 sítios de punção imediatamente após a remoção de cateteres periféricos originando uma média de 1,40 punções venosas por neonato. As complicações foram responsáveis por $48 \%$ da remoção dos cateteres, antes da alta do tratamento, com predomínio de infiltração $(79,2 \%)$, seguida por flebite $(16,7 \%)$ e extravasamento $(4,2 \%)$. A fim de se evitar os agravos e promover a segurança dos recém-nascidos submetidos à terapia intravenosa, a equipe de enfermagem deve avaliar periodicamente 0 acesso venoso periférico e obter conhecimento acerca das intervenções necessárias quando detectados sinais de complicações.
\end{abstract}

Descritores. Enfermagem. Recém-Nascido. Cateterismo periférico. Infusões Intravenosas

\section{Resumen}

El objetivo de este estudio fue describir la ocurrencia de flebitis, infiltración y extravasamiento en recién nacidos internados en la unidad de terapia intensiva neonatal de una maternidad pública de Rio de Janeiro. Se trata de un estudio cuantitativo descriptivo con 36 recién nacidos en uso de terapia intravenosa y con indicación de remoción del dispositivo intravenoso periférico. Fueron evaluados 50 sitios de punción inmediatamente después de la remoción de catéteres periféricos originando una media de 1,40 punciones venosas por neonato. Las complicaciones fueron responsables por $48 \%$ de las remociones de los catéteres, antes del alta del tratamiento, con predominio de infiltraciones (79,2\%), seguida por flebitis (16,7\%) e extravasamiento (4,2\%). Con el fin de evitar los lesiones y promover la seguridad de los recién nacidos sometidos a terapia intravenosa, el equipo de enfermería debe evaluar periódicamente el acceso venoso periférico y obtener conocimiento acerca de las intervenciones necesarias cuando detectadas señales de complicaciones

Palabras clave. Enfermería. Recién nacido. Cateterismo periférico. Infusiones intravenosas

\footnotetext{
${ }^{1}$. B.Sc. in Nursing - Escola de Enfermagem Anna Nery/UFRJ. Nurse, Pediatric ICU, Hospital Pró-Cardíaco. Rio de Janeiro - RJ. Brasil. Email:caroline@bol.com.br;²B.Sc. in Nursing - Nurse - Escola de Enfermagem Anna Nery/UFRJ. Rio de Janeiro - RJ. Brasil. Email: carolin-e@bol.com.br; ${ }^{2}$ Ph.D. in Collective Health. Researcher, Instituto de Medicina Social, Universidade do Estado do Rio de Janeiro (UERJ). Rio de Janeiro - RJ. Brasil. Email: carmen@ims.uerj.br; ${ }^{4}$ Ph.D. in Morphological Sciences. Adjunct Professor, Instituto de Ciências Biomédicas, Universidade Federal do Rio de Janeiro (UFRJ). Rio de Janeiro - RJ. Brasil. E-mail: jane@anato.ufrj.br, ${ }^{5}$ Ph.D. in Nursing. Adjunct Professor, Escola Paulista de Enfermagem. Rio de Janeiro RJ. Brasil. Email: ariane.machado@unifesp.br;'PPh.D. in Sciences. Adjunct Professor, Departamento de Enfermagem Materno-Infantil, Escola de Enfermagem Anna Nery-UFRJ. Board Member, Research Group on Child Health - NUPESC/EEAN. Rio de Janeiro - RJ. Brasil. E-mail: elisaelisa@terra.com.br
} 


\section{INTRODUCTION}

The intravenous route is the main access for medication administration in newborns hospitalized at neonatal intensive care units (NICU) and is vital to their survival. A study a five neonatal units in Rio de Janeiro evidenced that $99.6 \%$ of newborns below 1500 grams received intravenous drugs through different types of intravascular devices, which high usages rates for peripheral vascular devices ${ }^{1}$. In a study on the profile of newborns who had left the NICU, the authors found that peripheral venous puncture was the most used procedure in infants who participated in the Kangaroo Care Method at a federal public maternity².

Intravenous therapy (IT) incorporates knowledge, practices and technologies from different specialties, fundamental for newborn survival at the NICU. Despite the whole technological neonatal care apparatus, however, it entails risks and benefits and is potentially associated with different complications $^{3}$.

Preterm and critically ill newborns frequently need intravenous therapy for more than seven days, comprising different drugs that irritate the vascular endothelium, which hampers peripheral vascular catheter maintenance for the time needed and enhances the risk of complications like phlebitis, infiltration and extravasation. Venous network fragility, drug and solution characteristics and intravenous device types are factors contributing to the exhaustion of the newborn's venous network and the occurrence of multiple peripheral venous punctures during hospitalization. Few studies describe these events in neonates though and provide evidence to support intravenous therapy nursing practice ${ }^{3}$.

The goal of this study was to describe phlebitis, infiltration and extravasation events in newborns hospitalized at a neonatal intensive care unit. Due to the small number of Brazilian publications on intravenous therapy in the neonatal population, we intend to identify the occurrence of IT related complications in newborns attended at an NICU, as well as to contribute to evidence-based nursing care delivery to this group.

\section{LITERATURE REVIEW}

Pain and stress prevention and control through decreased painful procedures in neonatal units have been constantly evidenced in scientific literature. Painful and stressful stimuli produce inadequate neurobehavioral and hormonal stimuli that harm the development of preterm newborns, due to their physiological immaturity to overcome these events.

Excessive manipulation and painful procedures for a long time are harmful to newborn health and can alter many aspects of their brain development, besides provoking a reduction in the pain threshold and a state of hyperalgesia ${ }^{4}$. Considering newborns' vulnerability to complications deriving from excessive handling, obtaining safe and long-lasting vascular access is fundamental in neonatal care, with a view to avoiding repeated peripheral venous punctures and venous dissections.

The search for strategies to minimize and avoid pain is considered one of the most important steps to put in practice a humanized care model and improve the quality of life of newborns hospitalized at $\mathrm{NICU}^{5}$.

Care planning for newborns who need intravenous therapy should be based on guidelines that cover the choice of the best access type and intravascular devices, considering therapy duration, drugs characteristics and compatibility, besides the assessment of the child's venous network. Intravenous therapy quality is achieved when professionals manage to reduce related complications, the number of punctures, costs to optimize work and enhance patient safety. If intravenous therapy practice involves isolated technical procedures, however, without guidelines to orient the entire team, complication rates tend to increase, compromising patients' and health professionals' safety ${ }^{3}$.

To put in practice IT, professionals should choose the intravascular device according to the neonate's characteristics, duration and composition of the therapeutic plan, and discover the particularities of the newborn's body composition and homeostasis, among other aspects contributing to adequate nursing care delivery to newborns submitted to IT.

Newborns hospitalized at NICU have a lack of venous accesses due to adverse events that lead to the frequent loss of venous catheters, aggravating the problem the team faces to infuse multiple drugs within a short time period; thus, the administration of antimicrobials and other drugs in the therapeutic plan is delayed, enhancing the occurrence of medication errors and worsening the infant's clinical condition.

Errors in the administration of vasoactive drugs, electrolytes, glucose and antimicrobials can entail difficult hypotension control in the neonatal period, hydroelectrolytic disorders, hypoglycemia and increased risk of bacterial resistance. Hence, studies evidencing the factors involved in these events are extremely impor tant to allow nurses to plan and put in practice actions to prevent their occurrence ${ }^{3}$.

One factor that hampers care delivery to infants submitted to IT is the limitation of the venous network, conditioned by the infant's body composition that is still developing, turning the achievement and maintenance of peripheral venous accesses into one of the main neonatal care challenges. It demands aptitude, skill and mastery of care technology from nurses with a view to successful venipuncture and maintenance of peripheral venous access, free from complications ${ }^{6}$.

Phlebitis, infiltration and extravasation are described as adverse events, related to the use of peripheral intravenous catheters, which can result in potentially severe injuries and variable morbidity levels $s^{3}$. They are attributed to a range of factors, including catheter type, insertion site antisepsis, infusion type, insertion technique and site, dressing type and catheter dwelling time ${ }^{7}$.

Phlebitis is defined as the inflammation of the vein, infiltration as the unintentional administration of non-vesicant solutions into adjacent tissues and extravasation as the 
unintentional administration of vesicant solutions into adjacent tissues ${ }^{8}$. In general, these complications can be minimized through the indication of central venous accesses for the infusion of drugs with inadequate physical-chemical characteristics for infusion in peripheral veins. When a central intravenous device cannot be implanted, the use of peripheral veins demands continuous surveillance from the nursing team with a view to the early detection of phlebitis, infiltration and extravasation, avoiding these problems' evolution which, in case of extravasation, can reach deep tissues, including muscles and nerves, and possibly lead to limb amputation ${ }^{3}$.

To assess these complications and outline conducts in clinical practice, nurses can use the phlebitis and infiltration assessment scales of the Infusion Nursing Society $(\mathrm{INS})^{8}$, which provide parameters to assess the degree of injuries caused by phlebitis and infiltration, but these scales are inadequate for use in newborns. Hence, there is a lack of instruments that can help the nursing team to assess these complications in infants.

Newborns' risk of developing phlebitis is five times higher than in children older than one year. A study that assessed the dwelling time of peripheral venous catheters in 78 newborns demonstrated that $89.6 \%$ of peripheral intravenous devices were removed due to infiltration events ${ }^{9,10}$.

\section{METHOD}

Descriptive study on phlebitis, infiltration and extravasation events in newborns submitted to peripheral intravenous puncture with an over-the-needle catheter, hospitalized at an NICU of a public maternity hospital in Rio de Janeiro. Newborns were included in the study who were receiving intravenous therapy through a peripheral venous catheter and were indicated for removal of the intravenous device by the nursing team, after the parents or responsible caregivers' consent to participate in the research and according to the researcher' presence at the study unit. Convenience sampling was adopted due to limitations in the data collection process, exclusively linked to the researcher.

Immediately after the nursing team's removal of the intravenous device and practice of recommended comfort and pain prevention measures at the unit, the researcher assessed the newborns to identify clinical signs of phlebitis, infiltration or extravasation in the puncture site, which may have been responsible for the indication to remove the device. ${ }^{8}$

The collected data were registered in an instrument with variables on the characteristics of the children, administered intravenous therapy and assessment of the peripheral intravenous catheter withdrawal site. After receiving training, the researcher collected the data between July and October 2010, after getting approval from the institution and the Rio de Janeiro Municipal Health Secretary Institutional Review Board, protocol № 85/10 - CAEE0099.0314.226-10, in compliance with ethical aspects of research involving human beings. Data were analyzed through Epi-Info and results were presented as tables and a picture.

\section{RESULTS}

During the study, 50 peripheral intravenous catheter removal indications were identified in 36 newborns using intravenous therapy, resulting in a mean 1.40 punctures per newborn.

In all infants who participated in the study, 24-gauge Teflon ${ }^{\circledR}$ over-the-needle catheters were used, with IT infusion through infusion pumps with syringe and linear peristaltic mechanisms.

Table 1 displays the demographic characteristics of the newborns who participated in the study.

Table 1. Demographic characteristics of newborns hospitalized at a neonatal intensive care unit and submitted to intravenous therapy. Rio de Janeiro, 2010.

\begin{tabular}{|c|c|c|}
\hline Variables & $n$ & $\%$ \\
\hline \multicolumn{3}{|l|}{ Gender } \\
\hline Male & 20 & 55.6 \\
\hline Female & 16 & 44.4 \\
\hline \multicolumn{3}{|l|}{ Delivery type } \\
\hline Normal & 11 & 30.5 \\
\hline Cesarean & 24 & 66.7 \\
\hline Other & 1 & 2.8 \\
\hline \multicolumn{3}{|l|}{ Weight at birth } \\
\hline Extreme low weight $(<1000 \mathrm{~g})$ & 8 & 22.2 \\
\hline Very low weight $(1000<p<1499 \mathrm{~g})$ & 10 & 27.8 \\
\hline Low weight $(1500<p<2499 g)$ & 10 & 27.8 \\
\hline More than 2500 & 8 & 22.2 \\
\hline \multicolumn{3}{|l|}{ Gestational Age } \\
\hline Extremely premature & 7 & 19.4 \\
\hline Moderately premature & 19 & 52.8 \\
\hline Borderline premature & 2 & 5.6 \\
\hline Full-term & 8 & 22.2 \\
\hline \multicolumn{3}{|l|}{ Apgar 1st minute } \\
\hline Not informed & 1 & 2.8 \\
\hline Between 3 and 5 & 4 & 11.1 \\
\hline Between 5 and 7 & 6 & 16.7 \\
\hline Between 7 and 9 & 25 & 69.4 \\
\hline \multicolumn{3}{|l|}{ Apgar 5th minute } \\
\hline Not informed & 1 & 2.8 \\
\hline Between 5 and 7 & 4 & 11.1 \\
\hline Between 7 and 9 & 31 & 86.1 \\
\hline \multicolumn{3}{|l|}{ Venous network condition } \\
\hline Visible and palpable & 15 & 30.0 \\
\hline Visible and not palpable & 6 & 12.0 \\
\hline Not visible and palpable & 3 & 6.0 \\
\hline Not visible and not palpable & 26 & 52.0 \\
\hline
\end{tabular}


According to data in Table 1, the newborns were predominantly male, born through c-section, with very low or low weight at birth, moderately premature, with 1 and 5-minute Apgar scores ranging between 7 and 9 .

Table 2 shows the characteristics of the intravenous therapy administered to the infants who participated in the study.

Table 2. Characteristics of intravenous therapy administered in newborns hospitalized at a neonatal intensive care unit. Rio de Janeiro, 2010.

\begin{tabular}{|c|c|c|}
\hline Variables & $\mathrm{n}$ & $\%$ \\
\hline \multicolumn{3}{|l|}{ Days of previous $\Pi$} \\
\hline 1 to 20 days & 38 & 76.0 \\
\hline 21 to 40 days & 6 & 12.0 \\
\hline 41 to 60 days & 4 & 8.0 \\
\hline 61 to 73 days & 2 & 4.0 \\
\hline \multicolumn{3}{|l|}{$\begin{array}{l}\text { Previous use of central venous } \\
\text { catheter }\end{array}$} \\
\hline No & 37 & 74.0 \\
\hline Yes & 13 & 26.0 \\
\hline \multicolumn{3}{|l|}{ Scalp trichotomy } \\
\hline No & 34 & 68.0 \\
\hline Yes & 16 & 32.0 \\
\hline \multicolumn{3}{|l|}{ Catheter location } \\
\hline Upper Limb & 27 & 54.0 \\
\hline Lower Limb & 15 & 30.0 \\
\hline Cephalic Region & 8 & 16.0 \\
\hline \multicolumn{3}{|l|}{ Access type } \\
\hline Peripheral & 41 & 82.0 \\
\hline Peripheral and Central & 9 & 18.0 \\
\hline \multicolumn{3}{|l|}{ Infusion type } \\
\hline Continuous & 29 & 58.0 \\
\hline Intermittent & 21 & 42.0 \\
\hline \multicolumn{3}{|l|}{ Antimicrobial infusion } \\
\hline Yes & 32 & 64.0 \\
\hline No & 18 & 36.0 \\
\hline \multicolumn{3}{|l|}{ Vasoactive amine infusion } \\
\hline No & 46 & 92.0 \\
\hline Yes & 4 & 8.0 \\
\hline \multicolumn{3}{|l|}{ TPN administration } \\
\hline No & 32 & 64.0 \\
\hline Yes & 18 & 36.0 \\
\hline \multicolumn{3}{|c|}{ Calcium Gluconate solution infusion } \\
\hline No & 31 & 62.0 \\
\hline Yes & 19 & 38.0 \\
\hline \multicolumn{3}{|l|}{$\mathrm{KCl}$ solution infusion } \\
\hline No & 35 & 70.0 \\
\hline Yes & 15 & 30.0 \\
\hline
\end{tabular}

Legenda TPN: Total parenteral nutrition, KCL: Potassium chloride, NaCl: Sodium chloride.

Most newborns had received intravenous therapy before data collection for up to 20 days, through a peripheral venous catheter, installed in regions that did not demand scalp trichotomy. During current intravenous therapy administration, most catheters were inserted in upper limbs, with the predominant and isolated use of peripheral venous catheters. Regarding the way to infuse solutions, the predominance of continuous infusion was observed.
Most newborns received antimicrobial infusion, followed by total parenteral nutrition and calcium gluconate or potassium chloride solutions. A smaller group received vasoactive amine infusions (Table 2). 
Phlebitis, infiltration and extravasation in neonates

Picture 1. Antimicrobials used by newborns hospitalized at a neonatal intensive care unit submitted to intravenous therapy. Rio de Janeiro, 2010.

\begin{tabular}{|cc|}
\hline Antimicrobial & $\mathrm{Fi}$ \\
\hline Gentamicin & 12 \\
Ampicillin & 10 \\
Amphotericin B & 7 \\
Cephepime & 6 \\
Meropenem & 6 \\
Crystalline Penicillin & 5 \\
Vancomycin & 5 \\
Oxacillin & 1 \\
Piperacillin and Tazobactam Sodium & 1 \\
Total & $\mathbf{5 3}$ \\
\hline
\end{tabular}

According to Picture 1, the main antimicrobials that oxacillin and piperacillin and tazobactam sodium. Next, were administered were gentamicin, ampicillin, amphotericin Table 3 shows the assessed catheters' dwelling times.

B, meropenem, cephepime, vancomycin, crystalline penicillin,

Table 3 Dwelling time of peripheral venous catheters inserted in newborns hospitalized at a neonatal intensive care unit submitted to intravenous therapy. Rio de Janeiro, 2010.

\begin{tabular}{cccc}
\hline \multicolumn{1}{c}{ Variables } & $\mathrm{n}$ & $\%$ \\
\hline Dwelling time & & \\
$\quad$ Up to 24 hours & 25 & 50.0 \\
Between 24 and 48 hours & 11 & 22.0 \\
Between 48 and 72 hours & 8 & 16.0 \\
Between 72 and 96 hours & 2 & 4.0 \\
More than 96 hours & 4 & 8.0 \\
\hline
\end{tabular}

Regarding the dwelling time of the peripheral venous catheters inserted in the newborns who participated in the study, according to data in Table 3, half of the assessed catheters was installed for up to 24 hours.
Tables 4 and 5 show, respectively, data regarding the reasons for withdrawing the peripheral venous catheters inserted in the infants and local complications of intravenous therapy, including phlebitis, infiltration and extravasation.

Table 4. Reason for peripheral venous catheter withdrawal in newborns hospitalized at a neonatal intensive care unit submitted to intravenous therapy. Rio de Janeiro, 2010.

\begin{tabular}{lcc}
\hline \multicolumn{1}{c}{ Variables } & $\mathbf{n}$ & \% \\
\hline Local complications & 24 & 48.0 \\
Obstruction & 10 & 20.0 \\
End of intravenous therapy & 9 & 18.0 \\
Accidental removal & 7 & 14.0 \\
\hline
\end{tabular}

Local complication events were the most frequent obstruction, end of intravenous therapy and accidental catheter reasons for withdrawal of the studied catheters, followed by removal (Table 4).

Table 5. Occurrence of local complications of intravenous therapy, phlebitis, infiltration and extravasation in newborns hospitalized at a neonatal intensive care unit submitted to intravenous therapy. Rio de Janeiro, 2010.

\begin{tabular}{lccc}
\hline & Local complications & $\mathbf{n}$ & Fi\% \\
\hline Phlebitis & No & & \\
& Yes & 20 & $83.3 \%$ \\
Infiltration & & 4 & $16.7 \%$ \\
& No & 5 & \\
Extravasation & Yes & 19 & $20.8 \%$ \\
& No & & $79.2 \%$ \\
& Yes & 23 & $95.8 \%$ \\
& & 1 & $4.2 \%$ \\
\hline
\end{tabular}


Regarding local complications of intravenous therapy, data in Table 5 show higher frequency levels for infiltration, followed by phlebitis and extravasation.

\section{DISCUSSION}

Peripheral intravenous therapy is one of the most accomplished procedures in hospitalized newborns. Although different professionals consider it a simple and daily procedure, it requires care to avoid the occurrence of adverse events.

In view of the study population's demographic characteristics, higher frequencies were found for male newborns. Regarding the delivery type, the highest incidence levels were found for c-section, which has been considered an obstetric intervention related to the increased survival of highrisk newborns.

The analysis of weight at birth revealed that $27.8 \%$ of the study population corresponded to very low-weight $(1000<p<1499 \mathrm{~g})$ and low-weight $(1500<\mathrm{p}<2499 \mathrm{~g})$ newborns.

The predominant gestational age was moderately premature, followed by extremely premature. Morbidity and mortality risk in the neonatal period increases with lower weight and younger gestational age at birth ${ }^{11}$. Hence, the demographic characteristics justify the need for intravenous drugs and solutions as part of the therapeutic plans in the study population.

Regarding the number of intravenous therapy days, it was observed that $76 \%$ of the population received intravenous therapy before their inclusion in the study, for up to 20 days, a fact that could contribute to worsen the infants' peripheral venous network and influences the interruption of intravenous therapy.

A study at a pediatric surgery unit in São Paulo evidenced that most venous network assessments of children who participated in the study permitted identifying that they were visible and/or palpable ${ }^{12}$. In our study, on the other hand, in $52 \%$ of the subjects, the venous network condition was not visible and not palpable. This finding may be related with differences in the study population, as premature newborns have a more fragile venous network due to prolonged intravenous therapy with multiple irritant drugs and solutions, causing venous network exhaustion during hospitalization ${ }^{3}$.

As for the location of the intravenous device, upper limbs were the primary sites, followed by the lower limbs. This finding was also present in a research at an NICU in Rio de Janeiro, which revealed that the preferred site for venipuncture in newborns were the dorsal arch of the hand or metacarpal veins, followed by the veins located in the antecubital fossa and lower limbs - saphena e do dorsal arch of the foot. The veins located in the epicranial region were mentioned as the final option for venipuncture in newborns ${ }^{13}$.

Although most newborns are in no good peripheral venous network conditions, only $32 \%$ underwent scalp trichotomy. The nursing team has avoided removing the hair and puncturing the epicranial veins, as it has been considered an extreme measure, taken due to the lack of other puncture sites, as it alters the body image for the infant's parents and increases the risk of infection and other complications. When the venous network in the upper and lower limb is exhausted, however, the team uses the epicranial veins to avoid or retard venous dissection, besides trying to minimize delays in the administration of drugs and solutions in the therapeutic plan ${ }^{3,13}$.

The main reason to withdraw the intravenous devices was the occurrence of local complications, responsible for $48 \%$ of catheter withdrawal indications. In a study at a pediatric unit of an Australian hospital, complication events also were the main reason for peripheral intravenous catheter withdrawal, in $74.6 \%$ of the children studied ${ }^{9}$. These findings evidence the dimension of these events in the interruption of intravenous therapy at pediatric and neonatal units ${ }^{3}$.

A study at an NICU in Rio de Janeiro demonstrated that $49.2 \%$ of the newborns used only a peripheral device, while $45.2 \%$ used a peripheral and a central device, evidencing equivalence between the device types ${ }^{1}$. Our study showed a discrepancy, as $82 \%$ of devices the newborns used were peripheral and $18 \%$ peripheral associated with central.

The analysis of the previous central venous catheter use variable showed that $74 \%$ of the newborns had not used this device. This fact is relevant in comparison with the days of previous IT, as most $(76 \%)$ of the study sample had received intravenous therapy for up to 20 days and, in this case, the peripherally-inserted central catheter would be the most indicated, as one of its criteria for insertion is IT administration for more than six days, parenteral nutrition use, vasoactive drugs, sedation and some antimicrobials $s^{3,14}$.

Regarding the solution infusion method, continuous infusion was more frequent, in line with findings from a study at a pediatric unit in São Paulo, where the authors evidenced this infusion form in $90.7 \%$ of the children who participated in the research?

The most used drugs were antimicrobials (64\%), while the most frequent infusion solution was total parenteral nutrition (36\%). According to the INS, solutions with osmolarity of more than $600 \mathrm{m0sm} / \mathrm{L}$ and parenteral nutrition are inadequate for peripheral infusion and, hence, the central route should be used ${ }^{8}$. Nurses should choose the venous access type based on the patient's therapeutic plan and conditions, in order to prevent the emergence of complications like phlebitis, infiltration and extravasation. At the unit where data were collected, however, total parenteral nutrition was installed without using this criterion, which led to one severe case of extravasation identified during the study period.

According to Picture 1, the antimicrobials administered through peripheral intravenous devices were gentamicin, ampicillin, crystalline penicillin, cephepime, meropenem, vancomycin and oxacillin, drugs whose $\mathrm{pH}$ and osmolarity can cause venous endothelial lesions when 
administered through the peripheral route. ${ }^{15} \mathrm{~A}$ study at a public NICU in Rio de Janeiro evidenced that antimicrobials were the second most infused type of drug in preterm newborns weighing less than $1500 \mathrm{~g}^{1}$.

The dwelling time of $50 \%$ of the catheters was up to 24 hours, demonstrating the limited durability of the peripheral venous access in relation to the duration of the infants' intravenous therapy, which ranged from 1 to 73 days (Table 2).

On the other hand, according to the Centers for Disease Control and Prevention (CDC), in adults, catheters should be replaced within 72-96 hours. For newborns, however, no recommendation exists for replacement, due to the lack of scientific evidence that relates complication events with catheter dwelling time in children. Thus, the device should be kept in place until the end of IT or while clinically indicated ${ }^{16}$. In the present study, most intravenous devices were removed due to complications (Table 4).

Another complication observed was the obstruction of the peripheral intravenous device in $20 \%$ of the assessed puncture sites, related to catheter maintenance with saline solution. A study that compared three dressing types for peripheral intravenous catheters in children submitted to surgical procedures identified $11.5 \%$ of catheter obstruction events, representing a frequent adverse event during intravenous therapy in children?

Based on the assessment of data regarding phlebitis events, a frequency level of $16.7 \%$ was found, higher than the results of a study on adverse events while using peripheral intravenous catheters in children according to three dressing types, which identified $4.7 \%$ of phlebitis events ${ }^{7}$, most of which occurred in the group in which non-sterile adhesive tape was used to fix the device. In our study, in all newborns under assessment, intravenous catheter fixation with non-sterile adhesive tape was used.

According to the INS, acceptable frequency levels of phlebitis in any population, whether child or adult, should correspond to $5 \%$ or less 8 . In this study, frequencies higher than INS recommendations were found, demonstrating the need to assess and adapt nursing practice regarding the prevention of this type of complication. Literature mentioned the following main risk factors for phlebitis: use of continuous intravenous lipid emulsion feeding, infusion of lorazepam or aminophylline, catheter location (antecubital fossa, arm or leg), dressing type, physical-chemical characteristics of drugs and solutions $\mathrm{s}^{7,3,15,17}$

The analysis of the infiltration variable revealed $79.2 \%$ in the assessed newborns. A study involving children using three types of peripheral catheter dressings showed $55.3 \%$ of infiltration events in children who received sterile transparent film on the peripheral catheter insertion site ${ }^{7}$. Risk factors for infiltration are divided in mechanical: the small caliber and conditions of the vein, choice of the ideal catheter, choice of the insertion site, ineffective catheter fixation, patient activity, multiple punctures in the same site; physiological, such as coagulation on the cannula, clots or fibrin, and lymphedema; besides factors related with drugs and solutions like $\mathrm{pH}$, osmolarity, vasoconstriction potential and cytotoxicity.

Despite the highest incidence levels among complication cases, it could be observed that no specific care was performed, neither to prevent nor to treat injuries. The catheter was simply removed when the occurrence of infiltration was identified, and the device was inserted in another site, which the team considered routine ${ }^{18}$.

Regarding extravasation events, publications report on incidence levels ranging from $23 \%$ to $28 \%$. In this study, it was identified in $4.2 \%$ of newborns, deriving from total parenteral nutrition extravasation, resulting in a circumscribed lesion with a three-centimeter diameters, irregular reddish margins and pale bed on the newborn's lower limb, demanding initial specific care with mechanical wound debridement and hydrocolloid plate dressing.

\section{Study limitation}

The study limitation includes data collection linked with the researcher's presence at the unit under analysis, which interfered in the sample size.

\section{CONCLUSION}

In view of the study findings, it was observed that IT complications corresponded to $48 \%$ of reasons for peripheral intravenous catheter withdrawal in newborns, before discharge from treatment is indicated, predominantly infiltration, followed by phlebitis and extravasation.

In order to avoid further damage than complications can entail for newborns, nurses, who are responsible for IT practice, should periodically assess peripheral venous access sites and gain knowledge on what interventions need to be performed when signs of complications are detected. Therefore, it is extremely important to develop further research on the theme in this specific population, so as to complete knowledge gaps on intravenous therapy, including the elaboration of assessment and intervention protocols, besides the creation or adaptation of existing classification scales for phlebitis, infiltration and extravasation for neonatology, in order to guide nursing practice for newborns submitted to intravenous therapy and contribute to improve care quality and reduce neonatal morbidity and mor tality. 


\section{REFERÊNCIAS}

1.Menezes, SO. Avaliação do acesso vascular em neonatos com menos de $1500 \mathrm{~g}$ internados em unidades neonatais da SMS do Rio de Janeiro. [dissertação]. Rio de Janeiro: Instituto Fernandes Figueira, Fundação Oswaldo Cruz; 2005.

2.Cabral, IE, Rodrigues, EC. 0 método mãe canguru em uma maternidade do Rio de Janeiro 2000-2002: necessidades da criança e demanda de educação em saúde para os pais. Texto\& Contexto Enferm. 2006 dez; 15 (4): 629-36.

3.Rodrigues EC. Perdeu a veia: os significados da prática da terapia intravenosa em uma unidade de terapia intensiva neonatal do Rio de Janeiro. [tese]. Rio de Janeiro: Instituto Fernandes Figueira, Fundação Oswaldo Cruz; 2008.

4.Grunau, RE, Hoslti L, Peters JWB. Long-term consequences of pain in human neonates. Seminars in Fetal \& Neonatal Medicine 2006 Aug; 11 (4): 268-75.

5.Silva TM, Chaves EMC, Cardoso MVLML. Dor sofrida pelo recém-nascido durante a punção arterial. Esc Anna Nery. [periódico on-line]. 2009 dez [citado 2011 abr 25]; 13(4): 726-32. Disponível em: http:// www.scielo.br/scielo.php?script=sci_arttext\&pid=S1414$81452009000400006 \&$ lng =pt. doi: 10.1590/S141481452009000400006 .

6.Lourenço AS, Kakehashi, TY. Avaliação da implantação do cateter venoso central de inserção periférica em neonatologia. Acta Paul Enferm. 2003 abrl/jun; 16(2): 26-32.

7.Machado AF, Pedreira MLG, Chaud MN. Eventos Adversos relacionados ao uso de cateteres intravenosos periféricos em crianças de acordo com tipos de curativos. Rev Latino-am Enfermagem. 2008 maio/junho; 16(3): 362-67.

8.Infusion Nursing Society. Standards of Practice. Vascular acess device selection and placement. J Intraven Nurs. 2011 Jan/Feb; 34(1S): 37-48.

9.Foster L, Wallis M, Patersin B, James, H. A descriptive study of peripheral intravenous catheters in patients admitted to a pediatric unit in one Australian Hospital. J Infus Nurs. 2002 May/June; 25(3):159-67.

10.Gupta P, Ruchi R, Basus S, Faridi, MMA. Life span of peripheral intravenous cannula in a neonatal intensive care unit of a developing country. J Pediatr Nurs. 2003 Aug; 18(4): 287-92.

11.Ceccon MEJR. Newborn birth weight as a morbidity and mortality risk factor: what does it mean? Pediatria. 2007; 29 (3):162-64.

12.Avelar AFM. Ultrassonografia vascular na utilização de cateteres intravenosos periféricos em crianças: estudo clínico, randômico e controlado [tese]. São Paulo: Departamento de Enfermagem, Universidade Federal de São Paulo; 2009.

13.Cardoso JMRM, Rodrigues, EC Rodrigues, BMRD Faria, JCF. Escolha de veias periféricas para a terapia intravenosa em recém-nascidos: relatos da equipe de enfermagem. Rev RENE. No prelo 2011.
14.Câmara SMC, Tavares TJL, Chaves EMC. Cateter venoso de inserção periférica: análise do uso em recém nascidos de uma unidade neonatal pública em Fortaleza. Rev RENE. 2007 jan/abr; 8 (1): 32-37.

15.Salles IR, Rodrigues EC, Amaral JCF. Administração de antibióticos no recém-nascido prematuro: escolha do acesso vascular de acordo com o PH e a osmolaridade. Rev Pediatr SOPERJ. 2008 set; (supl.)

16.Centers for Disease Control and Prevention. Guidelines for the prevention of intravascular catheter-related infections; 2011.

17.Doellman D, Bowe-Geddes LA, Franklin M, Ledonne J, Donnell LP, Pettit J. et al. Infiltration and extravasation: update on prevention and management. The Art and Science of Infusion Nursing. 2009 Jul/Aug; 32 (4): 203-11.

18.Garland JS, Havens, P. Dunne WM, Hintermeyer MJ, Bozzete MJ, Wincek T, et al. Peripheral intravenous catheter complications in critically ill children: A prospective study. Official Journal of the American Academy of Pediatrics. 1992 Jun; 89 (6):1145-150.

\section{NOTE}

aProjeto de pesquisa desenvolvido com bolsa de iniciação científica Fundação de Amparo à Pesquisa do Rio de Janeiro (FAPERJ). Ano - 2010. Bolsista de Iniciação Científica. - Ana Caroline Rodrigues Gomes
Recebido em 14/07/2010

Reapresentado em 17/01/2011 Aprovado em 10/05/2011 